International Journal of Language Education and Culture Review, Vol.4 (1) June 2018, 90-97.

Available online at http://journal.unj.ac.id/unj/index.php/ijlecr

DOI: https://doi.org/10.21009/IJLECR.041.10

\title{
RELIGIOSITY OF THE CHARACTERS IN NOVEL API TAUHID BY HABIBURRAHMAN EL SHIRAZY (A SEMIOTIC STUDY)
}

\author{
Nurul Hayati ${ }^{1}$, Darmahusni ${ }^{2}$ \\ Senior High School of Al Azhar Syifa Budi Kemang ${ }^{1}$, Universitas Negeri Jakarta ${ }^{2}$ \\ nurul.hayati@unj.ac.id ${ }^{1,}$ darmahusni@unj.ac.id ${ }^{2}$
}

\begin{abstract}
The objective of this research was to understand comprehensively about religiosity of the characters in novel Api Tauhid by Habiburrahman El Shirazy based on a semiotic study. It was a qualitative research with content analysis method. The data were collected through literature study, observed matters related to the religiosity of the characters in novel Api Tauhid by Habiburrahman El Shirazy. The data analysis and interpretation include semiotic studies use the theory of Pierce seen from the dimensions of faith, Islam, and ihsan(virtue). The sense of faith can be seen from unity of God, Islam can be seen from the worship performed by the characters, and ihsan can be seen from the behavior and deeds of the characters. This research is expected to be useful in the process of learning language and literature, especially in the use of semiotic methods to facilitate students to understand literature and language.
\end{abstract}

Keywords: religiosity, semiotic, icons, indexes, symbols

Internalizing religion is a universal phenomenon of human in his life, meaning we can find human beings without science, art and philosophy, but not all humans have belief in divinity and religion. In addition to the universal, religious life in modern times is so complex. Many religions are embraced by humans today. Faith, belief, and cult of worship are also found in modern society today.

Religion is the key to history, we can understand the soul of a society, if we understand the religion. We do not understand the results of culture, unless we understand the faith or religion that inspired it. Religion is the threshold for all literature. Religion is the source of philosophy, the driving force behind the creation of literature and at the same time making literature or literary work lead to religion.

The linking of two things is based on the view that an author cannot be separated from the values and norms derived from religious teachings that appear in life. This view is closely related to the process of creating literary works, that literary works are not born in a cultural vacuum situation (Wulandari, 2012: 247)

Literary works as a result of the creative imagination of authors who come from objective reality cannot be separated from human life and religiosity existing in society. One of the values that guides people in behaving is the value of religiosity. The presence of the value of religiosity in literature is the existence of literature itself. In Indonesia, the values of religiosity include faith, Islam, and ihsan (virtue). Novels containing religiosity invites the reader to contemplate discovering these values and living the complexity of life in depth.

One novel that discusses the element of religiosity is the novel of Api Tauhid (Historical Book of the Mind Builder) by Habiburahman El-Shirazy. This novel is full of religious messages that are supported by the setting and style of the good and polite language. Api Tauhid, according to his author, is aimed at raising Muslim youth's awareness of religion and religious teachings by making a historical background. Api Tauhid is very interesting to reveal its content with various approaches because this novel is full of messages. Diana (2016: 117) states that novel is a beautiful literary work 
both language and content because it contains language that is artistic and full of meaning. Therefore, this novel is suitable to study based on semiotic approach. This is not an exaggeration because the novel of Api Tauhid is written by the author using various signs in expressing his ideas. Signs in this case are the signs relating to icons, symbols and indexes for example in implying the contents of a Qur'anic verses and hadith through the behaviors and dialogues brought by its characters. Relevant research related to Novel Api Tauhid by Habiburrahman El Shirazy is research conducted by Gunawan and Emzir entitled Values in Dakwah in Habiburrahman El Shirazy Novel ( Genetic: Structuralism Study)( http://journal.unj.ac.id/unj/index.php/ijlecr/article/view/6192) The purpose of this research is to know the values of dakwah in novel Habiburrahman El Shirazy.

By using semiotic approach, the researcher will look at the signs associated with icons, symbols and indexes that can clearly reveal the forms of religiosity of the characters so as to provide an understanding of the importance of religiosity in life and also provide exemplary.

The word religius comes from religious relating to religion or the nature of religion attached to a person (Tontowi, 2005: 1). Ancok and Suroso (2015: 77) interpret religius from a psychological point of view. According to Ancok and Suroso, religius is the institutionalized system of symbols, beliefs, values and behaviors, all of which center on issues that are lived as the ultimate meaning.

The paradigm of equilibrium in religious reason and religious social action is directed to form the dimensions of human religious consciousness. As a part of God's most glorious creation above the other degrees of God's creatures, it is obliged to understand the inherent dimensions of religiosity of the self. Mudzakir (2004: 13) explains briefly the three dimensions of religiosity that are consistent with the hadith of the Prophet, namely the belief dimension of the creed or belief in fundamental things such as the matter of faith in God, angels, the apostles of Allah, the Qur'an as revelation, days of end, and destiny. Islamic dimensions of worship or worship that show obedience and are realized in trust, both vertically (individual) and horizontally (social), such as reciting the two sentences creed, praying, paying zakat, fasting, and hajj for the capable. The dimension of goodness is to do good or good morals, which shows the quality of a person such as doing justice, defending the truth, being honest, keeping the mandate, helping, generous, good to family, neighbors, peers, and to the nation. To uncover the values of religiosity a semiotic approach is one approach that can be used to analyze signs.

The theory of Pierce became grand theory in semiotics. Pierce wanted to unpack an entire language. Thus, Pierce reveals a theory that reveals the overall meaning, the "Triadic Theory" of "signs" (Cobley \& Jans, 2002: 4). Pierce says that a direct connection with a sign, which can be termed a representament, has a direct connection to an object requiring an interpretant.

Budiman (2005: 56-57) outlines the main triadics of Pierce by starting from the icon. icons are marks based on resemblance between representament and object, whether or not the object exists. Then he elaborates the concept of index. Index is a sign that has a physical, existential, or causal links between the representament and its object so as to lose the character that makes it a mark if the object is moved or removed. The three sages described the symbol. A symbol is a sign that its representation refers to a particular object without motivation. Symbols are formed by conventions or rules, with no direct connection between representament and object. Ferdinand de Saussure defined as an arbitrary characteristic of sign.

Another opinion was also given by Basalamah (2008: 27-28). Basalamah jotted down the icon into three sections, the topological icons which mean the resemblances seen here are spatial similarities, diagrammatic icons that reveal relational resemblance and metaphorical icons meaning no resemblance between the sign and its reference. Similiatrity is not a sign with reference, but between two references referred to by the same sign. Index is a sign that has a relationship of existence, and symbol is a sign conventionally formed.

Semiotics is not just a theory, but it can be applied in a scientific study. Semiotics can be used to interpret the signs systematically including the literary works. Semiotics can interpret the 
signs associated with various aspects of literature. Literary works is a compact mix between its elements so it requires semiotic analysis to interpret literature in depth.

The research on the religiosity of figures with semiotic reviews has also been studied by Ismiatun (2014) using the novel Ayat-Ayat Cinta by the same author Habiburahman El Shirazy. Ismiatun used semiotic approach in analyzing the data, but the difference is Ismiatun research with semiotic method seen from heuristic reading and hermeneutic reading, whereas this research uses semiotic method of Pierce' Triadics.

Based on the above descriptions, this research has a general purpose and a special purpose. The general aim is to gain a deep understanding of the religiosity of the characters in the novel of Api Tauhid by Habiburrahman El Shirazy using a semiotic approach. The specific purpose of this study is to deeply examine the religiosity of the characters in the dimensions of faith, the dimensions of Islam, and the ihsan (virtue) dimension in terms of semiotic pierce signs of icons, indexes, and symbols.

\section{METHOD}

This research uses qualitative approach with content analysis method to the novel Api Tauhid by Habiburrahman El Shirazy. The literary approach used is the semiotic approach. In this study, data collection techniques are conducted through library study, observing matters relating to the religiosity of the characters in the novel Api Tauhid by Habiburrahman El Shirazy in the form of words, phrases, clauses and sentences.

In addition to the techniques, there are also data collection procedures. The procedures used to collect data in this study include reading and understanding the contents of novel Api Tauhid by Habiburrahman El Shirazy as a source of data on research, making a note in the form of abstraction or description of each event which is the element of religiosity in the novel, identifying aspects which are listed in the research objectives, and then performing data analysis and interpretation.

\section{RESULTS AND DISCUSSION}

The results of data analysis that has been done writer in reviewing signs of semiotic icon, index, and symbol on Novel Api Tauhid by Habiburrahman El Shirazy can be seen that the signs exist in the whole contents of the novel. The signs are used to examine the religiosity of figures from the dimensions of faith, Islam, and ihsan (virtue).

\section{The Religiosity of Characters Viewed from Icons}

\section{a. Dimension of Faith}

The religiosity of the characters in the faith dimension of the iconic sign is found only five pieces of data from the entire contents of the novel. The icon marker on the dimension of faith is told with Fahmi's happiness if only he was in the time of the Messenger of Allah, if it were at that time, he would welcome the Messenger of Allah with a happy and loving heart. He will embrace the Messenger of Allah. The sentence of happiness though only imagine is a representation that refers to the love and faith to the Prophet Muhammad even though the distance lies a very long distance. This phrase indicates that Fahmi believed the Prophet Muhammad was the messenger of Allah.

Strive in the way of Allah! God is Most Helpful! Bullets and grenades can not kill you! Only the power of God is killing you! ..... "(p.384).

The expression of faith through icons is seen from the representament only the power of God who kills you which refers to a very strong form of faith to the fate and power of God, namely: a metaphorical relationship between strong faith and no fear of jihad in the way of God.

Suddenly, he remembered reading surah Al-Ikhlas, whose magnificence was like reading a third of the Qur'an. He lived, because in the letter of Al-Ikhas there is affirmation of Tauhid. (p.79.) 
The semiotics emerging from this quote are metaphorical icons of reading surah Al-Ikhlas as powerful as reading one third of the Qur'an. The object is to read the surah Al-Ikhlas. The relationship between representament and objects forms an interpretation that simply reading surah Al-Ikhlas alone is like reading one third of the Quran.

\section{b. Dimension Of Faith}

The semiotic symbols of icons in the Islamic dimension mostly use the metaphorical icon marks. The Islamic dimension is a dimension that explains the laws of shari'a or worship. As explained in the introduction, the Islamic dimension is to perform such worship as prayer, fasting, zakat, hajj pilgrimage, prayer, and other forms of worship.

The icon existing in the dimensions of Islam is shown by the phrase It seems Mirza leads the oxen to dhikr (remember) to God before the sun rises in the eastern horizon, dhikr is one form of worship to God. The sentence includes a metaphorical icon because animals can not actually (remember) dhikr like a human being of dhikr. Animals or other created beings of God have their own way of worshiping God. The word $d h i k r$ here is all the form of a rod that resembles human behavior. Other icons contained in the Islamic dimension are included in the quote. All those who know Said Nursi describe him as a very serious person in worship this shows Islam in the word worship. Representament is a word depicting with Said Nursi as an object. The word describes is a form of similitude in the form of oral, that is telling something according to what is really. Everyone who knew Said Nursi told him based on what really happened as a very serious person in worship.

\section{c. Dimension Ihsan (Virtue)}

The dimension of ihsan is a dimension that is more related to the form of consequences that the religious community considers to its responsibility as a human being. The forms of the ihsan dimension can be a sense of humanity like help, good to anyone, responsible for the work, and not harming others. Ihsan dimension is more to human relationships between people who are directly accountable to God.

In the semiotic sign of the icon, the ihsan dimension has the most data compared to the dimensions of faith and the dimensions of Islam. There are 7 data using the semiotic sign of the icon.

An icon in the ihsan dimension is indicated by the following sentence quotation:

Nur Jannah kisses my mother's right hand as if she were her mother's hand. While my mother's left hand stroked the head of Nur Jannah lovingly. (p.38)

This quote shows the object that Nur Jannah respects mother of my character as if she were her own mother. The reprasentament is a metaphoric icon that Nur Jannah kisses my mother's right hand as if it were her mother's hand. This highly polite attitude of Nur Jannah is an interpretation of the ihsan attitude of a religious person. The mother of my character also replied to Nur Jannah's attitude by caressing the head of Nur Jannah lovingly.

Another iconic sign is contained in the quote he welcomes me warmly. The warm word is a representament of the object of one's attitude toward another. Warm words have a sense of something that makes you comfortable. This warm word is then used to describe the attitude of someone who is friendly, courteous and fun. The attitude of such a person is likened to the meaning of the word warm. Having a warm attitude towards others is an implementation of the ihsan dimension.

\section{The Religiosity of People is viewed from the Index}

Index is a semiotic sign indicating causality or causal relationship (Berger, 2010: 16). Like icons, the religiosity studied using the index also consists of three dimensions, namely the dimensions of faith, the dimensions of Islam and the dimensions of ihsan. Based on the findings of research data in chapter IV religiosity observed from the index found data dimension of priests with semiotic index sign of 27 data, Islamic dimension amounting 30 data, and dimension ihsan amounting 107 data. 


\section{a. Dimension of Faith}

"when I have no intention of wanting to commit suicide I can not do it, I am a believer." (p.19).

The semiotics emerging from this quote are indexes because markers and markers show a causality relationship. Representamen no intention at all I want to commit suicide that refers to me a believer. This shows the interpretation of my character who has no intention of killing and is unlikely to perform such acts because he is a believer.

Suicide is strictly prohibited in Islam because it means preceding God's decree. Only Allah is entitled to take the life he has given. The suicide battle is regulated in Al-Quran An-Nisa verse 29 which means "Thou shalt not kill thyself, lo! Allah is thy giver unto thee."

\section{b. The Islamic dimension}

The index marks in the Islamic dimension can be attributed to a form of causal relationship that refers to worship. Fahmi's unbroken sentence pronounced the tasbih seeing the sight that for him is so amazing it shows the index in the dimensions of Islam. The unending representament uttering the tasbih with the object of awe seeing a landscape has the contact of the causality of pronouncing the tasbih as a form of admiration. Sentence tasbih that reads Subhanallah which has the most holy meaning of God is a sentence that glorifies the greatness of God as the creator. Saying this sentence is also worth worship because this sentence is the dhikr most beloved of Allah and can be the slain of sin.

This is explained also in the hadith of the Muslim narratives which reads the Prophet SAW asked, "What is the most important thing?" He replied, "Allah chooses for the angels or His servants, that is 'Subhaanalah wa bihamdihi' (Glorified God by praise Himself).

In the novel Api Tauhid is told the figure of Nuriye Said Nursi's mother who is very devout worship. Even when she was pregnant with her children, including when Said Nursi was pregnant, Nuriye always kept herself in a holy state and never left the evening prayer, except when aged.

Never leaving prayer and always keeping yourself in a holy state is a form of one's obedience in worship to God. When pregnant, Nuriye always keep himself in a holy state and never leave the evening prayer is one form of Nuriye as a muslim statement, he also educates the child in his womb to worship God since in the womb. This is a sign of an index because it has a causal relationship.

\section{c. Dimension Ihsan}

The dimension of ihsan is the highest form in one's religiosity. Faith and worship is a direct relationship of a servant with his creator. Unlike ihsan that can be the embodiment of the attitude of faith and Islam. A person can be truly religious when he can apply his faith and worship with his attitude to the surrounding community or to other God's creatures.

Habiburrahman also in the novel of Api Tauhid is more to include the religiosity of the ihsan dimension. This is evidenced by 107 data found, far more than the dimensions of faith and Islam.

One of the ihsan dimensions in the semiotic sign of the index is seen from the following quote:

Knowledge obtained by you (Bapak) during the pesantren (Islamic boarding school) is enough to answer the needs of the village community ..... So since young, people in my village strongly believe in you (Bapak), so you are asked to be a modin (religion affairs servant). (p.27)

Representament of knowledge obtained by Bapak during the boarding school is enough to answer the needs of rural villagers has the object people in my village strongly believe in Bapak with interpretan Bapak became a trusted person in the village, so he was appointed to be a modin because it once went to school in the pesantren. The relationship between the representament and the object has a causality relationship so that the semiotic sign used is the index.

The ihsan dimension marked with the index is also evident from Fahmi's attitude which forbade his father to buy cigarettes for Pak lurah. Fahmi Representamen forbids you from buying cigarettes referring to redundant cigarettes and endangering the health of having a causality relationship with 
the semiotic sign of the index. Fahmi's father wanted to buy a pack of lurah cigarettes for wanting to glorify guests, the headman who smokes, wants to come and because he wants to respect his guest. Fahmi forbids because it is tantamount to endangering the health of lurah. Fahmi's attitude is a caring attitude to fellow human beings.

\section{The Religiosity of Character Viewed from Symbols}

Symbol is a manifestation of a thing that is a convention that applies to a society. The symbols that researcher finds in this study is a symbol that researcher interprets on the basis of existing knowledge in a culture in society.

The data that the researcher quotes only in the form of a symbol that has a connection with the religiosity of figures of three dimensions, namely the dimensions of faith, dimensions of Islam, and dimensions ihsan.

\section{a. Dimension of Faith}

The dimension of faith with the sign of semiotic symbols was found in 14 data. One form of symbol is seen in the excerpt of the shout of takbir that burns the spirit of the entire army of Islam refers to the object of faith to God. Sultan Muhammad II gave command to his troops as he would seize the konstatinopel by shouting takbir to incite his troops. This shows that Takbir is a symbol of the strength of the Islamic Ummah. Shouting God Almighty becomes the conviction of the people of God to be with them.

Another symbol in the dimensions of faith can be seen from the following sentence quotation:

I want to be iktikaf (one who submits to God) with unbearable soul sadness, but I oppose it with my Al-Quran recitation. I want to fight my holy love glow to my wife who has been seared with a greater light of love that is the light of love for the divine. (p.68).

I want to fight my holy love light on my wife who has been seared with a greater light of love that the light of love for the Divine is representation in symbolic form. The object is faith and ketauhidan (monotheism) to God. The relationship between representament and object shows that Fahmi's figure glorifies and puts God first on everything. At that time Fahmi was feeling disappointed with his wife, he felt very sad, he felt his sacred love was not appreciated by his wife, for that for the sake of treating his wound he realized that there is no greater love than God. Love to God is the symbol of a servant's absolute.

\section{b. The Islamic dimension}

The dimension of Islam is related to worship. The dimension of Islam in terms of the symbolic semiotic symbol consists of 58 data. One of the symbols in the dimensions of Islam that researcher found in this novel is the hijab. Jilbab is a symbol of the obedience of a Muslim against his religious orders. The veil rules for Muslim women have also been arranged in Al-Quran Al-Ahzab verse 59 which reads "O Prophet, say to your wives, your daughters and the wives of the believers: 'Let them extend their veil to the whole body them. "That is so that they are easier to recognize, so they are not disturbed. And Allah is the Forgiving, the Most Merciful".

From the above paragraph it can be concluded that the veil in addition to functioning as a cover of aurat and maintain the honor of women, is also a symbol for Muslim women. The word of God which reads "that they may be recognized" is evident. The veil belongs to the dimension of Islam because the veil is God's command, obeying God's commands is part of worship.

Another symbol found in the novel Api Tauhid is Qibla. After the marriage ceremony, Fahmi invited Nuzula to perform two rak'ah prayers. When going to hold a prayer mat, Nuzula straighten the direction of Fahmi's direction. "... The Qiblah is in the direction of the mirror," Nuzula quietly straightens the direction of Qiblah, Nuzula's action straightening the direction of the Qiblah is the object of the symbol representation. When carrying out the prayer a Muslim must face the direction of Qiblah The muslim is the kabah and the whole Ummah Muslims must pray to the kabah is a symbol 
of keeping the unity of the Ummah The direction of Qiblah should be equated so as not to break up the Ummah.Kiblah is the unifying symbol of the ummah.

Another symbol that appears is ablution (wudhu). Excerpts of the phrase "Get ritual ablution water, pray two rak'aah, ask Allah to be cleaned up and bestowed" shows that wudhu is a symbol of the purification process of a Muslim before performing the prayer, before reading the Qur'an a Muslim is required to perform ablution. Ablution is not merely a ritual but rather a soulcleansing process, a Muslim is also advised to perform ablution if the condition is in a state of anger, cleanses the heart and returns to purify the soul. Huds is a symbol of the Islamic dimension because wudu is part of worship.

\section{c. Dimension Ihsan}

The semiotic symbols contained in the ihsan dimension of the novel Api Tauhid found 31 data. The shape of the symbol is contained in the phrase Nur jannah and his family is like a full moon that shines brightly, .... Kyai Arselan and his family was a bit of a sun. The meaning of this utterances is Nur Jannah and her family are also good family and descendants, but with the almightyness of the family of Arkian kyai she becomes more luminous and bright. The sun and moon are the symbols, the praise form of the Fahmi family. Indicates the Fahmi family has positive thoughts towards others who are ihsan attitude in relationship muamalah.

Other symbols can be seen from the following citation:

all this time I always keep my eyes, trying desperately not look at women except my mother and my sister. During this time I also tried desperately to keep my heart so as not to fall in love with women who are not kosher. (p.57)

a Muslim man is obliged to keep his eyes from a woman who is not lawful for him. Maintaining this view is a form of respect for women in Islam. Representament all this time I always keep the view is a symbol that shows that Fahmi is a religious man who is very respectful of women.

Another quote in the form of symbols and is the dimension of keihsanan (virtue) is pak lurah (head of villagers) be broadminded . Be broadminded are representatives of objects having patience and being able to accept things with pleasure. The interpretation of this phrase is linked to the village head family who asked Fahmi earlier to become husband of Nur Jannah, the daughter of the village chief, but the Arselan kyai family was also interested in Fahmi and asked him to also be the husband of Nuzula, the youngest daughter of Arselan kyai. Fahmi's family decided to choose Nuzula, when this decision was submitted to the headman, he accepted it gracefully, with an open heart without anger. A breastplate is a symbol of patience.

The icons, index, and symbol symbols serve to illustrate and clarify the story. In addition, the use of icons, indixes, and symbols also serves to embellish the use of language so that the reader enjoys the contents of Habiburrahman El Shirazy's novel. Feelings of enjoyment will make the reader more able to understand the meaning to be conveyed by the author so the message conveyed.

\section{CONCLUSION}

Religiosity in this research consists of three dimensions, namely the dimension of faith, the dimension of Islam and dimension of ihsan (virtue). The first semiotic sign used to review the religiosity of a character is an icon. The icon is a semiotic sign that shows the similarity between the representament and the object. Icons also fall into several categories, topological icons, diagramic icons, and metaphorical icons. In the novel Api Tauhid, it is found $5(1.77 \%)$ data with the sign of the semiotic icon on the dimension of faith, $2(0.72 \%)$ data with the icon on the dimension of Islam, and $7(2.50 \%)$ data with the sign on the dimension of ihsan. All in all, only $4.99 \%$ of the data with the semiotic symbols of the icon on the novel Api Tauhid. The data found in the novel of Api Tauhid with semiotic index sign is quite a lot. There are 27 data (9.60\%) in the faith dimension with semiotic index sign, 30 data (10.67\%) on the dimension of Islam and the most is in ihsan dimension of 107 
data $(38,07 \%)$ with semiotic index sign. Overall there are 58.97 percent of novel content using index marks. Semiotic sign in religiosity of faith dimension was found as 14 data (4,98\%), 58 data $(20,64 \%)$ in Islamic dimension and 31 data $(11,03 \%)$ in ihsan dimension. Overall, there are $36.65 \%$ percent of the novel content using the symbolic semiotic sign.

A good cultural community is a society that has a high reading interest. Currently the government is actively launching literacy movements in schools to foster interest in reading. This research is expected to give educational implications for the world of literacy in society. Through this research community can more easily understand the story by knowing semiotic study, understand the meaning of sentences and get more vocabularies. Hopefully, the interest of reading community becomes more and more.

\section{REFERENCES}

Ancok, Djamaludin dan Fuad Nashori Suroso. Psikologi Islami, Solusi Islam atas Problem Psikologi. Yogyakarta:Pustaka Pelajar, 2010

Basalamah, Aly Abubakar. Semiotika dan Penerapannya dalam Studi Sastra. Yogyakarta : Perpustakaan Digital UIN Sunan Kalijaga, 2008

Berger, Arthur Asa. Pengantar Semiotika. Yogyakarta:Tirta Wacana, 2010

Budiman, Kris. Ikonitas Semiotika Sastra dan Seni Visual. Yogyakarta:Buku baik, 2005

Cobley, Paul dan Litza Jans. Mengenal Semiotika. Bandung:Mizan, 2002

Diana, Ani. Kajian Semiotik Pada Kumpulan Cerpen Sekuntum Mawar Di Depan Pintu Karya M.Arman A.Z., Jurnal Pesona Volume 2 No.1, 2016

Gunawan, dkk. "Values Of Dakwah in Habiburrahman El Shirazy Novel (Genetic Structuralism Study). International Journal Of Language Education Cultural Review, Vol.3(2) December 2017

Ismiatun. Aspek Religius dalam Novel Ayat-Ayat Cinta Karya Habiburrahman El Shirazy: Tinjauan Semiotik, Kajian Lingiusitik dan Sastra, Volume 26, no.1, 2016

Mudzakir, Jusuf. Fenomena Psikologis terhadap Religius dan Religiusitas, Jurnal Transformasi Kependidikan dan Keagamaan. Jakarta : Bidang Kajian Masjid Baitut Tholibin, 2004.

Tontowi, Ahmad. 2005. Hakikat Religiusitas. Sumatera Selatan: Balai Diklat Keagamaan Palembang. www.kemenag.go.id. (diakses November 2017)

Wulandari, Vivi. Perbandingan Religiusitas Tokoh Mualaf dalam Novel Ayat-Ayat Cinta Karya Habiburahman El Shirazy dan Novel Ternyata Aku Sudah Islam Karya Damien Dematra., Jurnal Pendidikan Bahasa dan Sastra Indonesia, Vol.1 No.1, Seri B 87, 2012. 